\title{
Kehittävän työntutkimuksen peruskäsitteitä ${ }^{1)}$
}

\begin{abstract}
Engeström, Yrjö 1985. Kehittävän työntutkimuksen peruskäsitteitä. Aikuiskasvatus 5, 4, 156-164. - Kehittävä työntutkimus on nopeasti kehittyvä uusi, monitieteellinen lähestymistapa työn ja koulutuksen tutkimuksessa ja kehittämisessä. Sen perustana on kulttuurihistoriallisen toiminnan teorian muodostama paradigma. Tässä artikkelissa hahmotellaan pelkistetty yleiskuva tästä lähestymistavasta ja sen peruskäsitteistä. Näin ollen käsitteiden historiallinen johtaminen ja konkreetit sovellusesimerkit jäävät pakostakin niukoiksi. Tämän numeron muissa artikkeleissa annetaan esimerkkejä lähestymistavan soveltamisesta. Lähdeluettelossa mainitut tekstit puolestaan tarjoavat kiinnostuneille lukijoille mahdollisuuden tutustua seikkaperäisemmin käsitteiden perustaan.
\end{abstract}

\section{Miten työtä on tutkittu?}

Työ tuntuu työntekijästä usein itsestäänselvältä asialta. Se on ikäänkuin työntekijän nahan alla, osa häntä itseään. Kuuluisa lastenkirjailija Eduard Uspenski (1981) kertoo krokotiili Genasta. Gena ilmoittaa olevansa töissä krokotiilina eläintarhassa. Toisien sanoen: olen krokotiili, työni on krokotiilina olemista. Sama tuntemus on monella alansa taitavalla käsityöläisellä - olen sorvari, sorvaaminen on sitä mitä teen. Tämä perinteinen ammattikuntakeskeinen ajattelutapa näkee työn vahvasti yksilöön ja hänen taitoihinsa kiinnittyvänä. Ammattitaito on jotakin julkilausumatonta, perinteen ja kokemuksen kautta hioutunutta, henkilökohtaista. Siksi työssä ei ole mitään tutkimista.

Työn tutkiminen nousee yhteiskunnalliseksi välttämättömyydeksi vasta teollisen vallankumouksen ja siihen liittyvän rationalisointipyrkimyksen myötä.

1) Tämä artikkeli on muokattu Seppo Kontiaisen toimittamassa raportissa "Näkökulmia aikuiskoulutuksen tutkimukseen" (Helsingin yliopiston kasvatustieteen laitoksen tutkimuksia 107) ilmestyneen artikkelin pohjalta.
Varsinaisen työntutkimuksen lähtökohta on epäilemättä sopeuttava. Sopeuttava tutkimusote näkyy työprosessin tekniset, taloudelliset ja organisatoriset ehdot valmiina, ylhäältä annettuina; työntekijät on tutkimuksen avulla saatava täyttämään nämä ehdot mahdollisimman tehokkaasti ja häiriöttömästi. Sopeuttavaa työntutkimusta puhtaimmillaan edustavat teollisuuden liike- ja aikatutkimukset (MTM ym.), joilla pyritään karsimaan tarpeettomat liikkeet ja osavaiheet pois työsuoritusten nopeuttamiseksi ja tehostamiseksi. Nimike "työntutkija", viittaa vieläkin juuri tämän tyyppiseen rationalisointitoimintaan. Sopeuttavaan tutkimukseen kuuluu myös työnhakijoiden "ominaisuuksien" perinteinen testaaminen.

Sopeuttavan työntutkimuksen rinnalla erottuu pian toteava tutkimusote. Toteava työntutkimus lähtee liikkeelle työvoimaa koskevasta tilastoinnista. Esimerkiksi Englannin hallituksen viranomaiset teettivät tällaisia selvityksiä jo varsin varhain huolestuneina teollisen vallankumouksen haittavaikutuksista. Suuri osa viime vuosikymmenien sosiologisesta työntutkimuksesta on ollut toteavaa. Tilastoaineiston perusteella on tehty johtopäätöksiä esim. työvoiman ammattitaidon tason kehityk- 
sestä. Tämä johti tunnettuihin teeseihin ammattitaidon alenemisesta (dekvalifikaatio) tai työvoiman jyrkästä jakautumisesta ammattitaidottomaan enemmistöön ja korkeasti ammattitaitoiseen pieneen vähemmistöön (polarisaatio) teknologisen kehityksen myötä. Kuten Toikka (1984) on osoittanut, näiden teesien kestämättömyys on siinä, että kuvitellaan "ammattitaito" laadultaan vakioksi suureeksi, jossa on kyse vain määrän tai tason muutoksesta. Kun käsityömäinen ammattitaito tosiasiallisesti häviää, jää toteavan otteen edustajilta havaitsematta, mitä laadullisesti uutta samalla kehkeytyy. Aivan viime vuosina toteava tutkimusote on joutunut kriisiin. Eräät sen tunnetut edustajat, näkyvimmin polarisaatioteesin kehittäjät Kern ja Schumann (1984), ovat todenneet, että heidän 1970-luvun alussa esittämänsä väitteet ovat käytännössä kumoutuneet ja monilla aloilla on syntymässä kokonaan uudenlaisia ammattitaidon tyyppejä.

Myös korjaavalla tutkimusotteella on vanhat perinteet. Korjaava työntutkimus pyrkii lievittämään työn vallitsevista teknisistä, taloudellisista ja organisatorisista ehdoista seuraavia haittavaikutuksia ja lisäämään mahdollisuuksia "inhimilliseen työhön". Samalla se kuitenkin säilyttää näkemyksen työn reunaehdoista jonakin ylhäältä annettuna. Näitä reunaehtoja pyritään kyllä väljentämään ja pehmentämään, mutta työntekijä on edelleenkin ensisijaisesti "uhri" tai "'kohde"'. Suurin osa työsuojelututkimuksesta edustaa tätä otetta, ja kehittyneimmillään se esiintyy työn "humanisointipyrkimyksissä'.

Voidaan myös erottaa pyhittävä tutkimusote omana linjanaan työn tutkimisessa. Tällä tarkoitetaan varsinkin monille toimintatutkimuksille ominaista käsitystä, jonka mukaan työntekijöiden "'omat", heitä "'itseään" ja heidän arkikokemustaan ilmaisevat pyrkimykset ja ajatukset on asetettava tutkimuksen ehdottomaksi ohjenuoraksi. Toisin sanoen työntekijöiden arkikokemus pyhitetään, koska tutkija ei tällöin enää "manipuloi"' kohdettaan, vaan pikemminkin osallistuu työntekijöiden pyrkimyksiin ja tukee niitä niiden "omilla ehdoilla"'. Tällainen ote uskaltaa ehkä jo asettaa kyseenalaiseksi työn reunaehtojen koskemattomuuden, mutta reunaehtoihin vaikuttaminen jää voimattomaksi, koska työntekijöiltä pelkän arkikokemuksen varassa puuttuu siihen välineet eikä tutkija itse uskalla tai kykene tällaisia uusia välineitä kehittelemään. Esimerkin tällaisesta otteesta tarjoaa Fricken ym. (1981) tutkimus, jota Toikka (1983) on eritellyt.

Kehittävä tutkimusote lähtee siitä, että työn reunaehdot eivät ole - ja ovat yhä vähemmän vastaisuudessa - puhtaasti ylhäältä annettuja välttämättömyyksiä. Todellisuudessa työ kokonaisuudessaan on alinomaisessa muutoksessa, ja tämä muutos ei koskaan tule yksisuuntaisesti ulkoa ja ylhäältä. Se, miten organisaatio määrittelee tuotantonsa kohteet, tavoitteet ja tuotteet, miten se valitsee välineistönsä, teknologiansa ja työnjakonsa - kaikki tämä muovautuu alituisesti paljolti sen perusteella, miten työntekijät suoriutuvat työstään, millaisia tuloksia he saavat, miten he työhönsä suhtautuvat. Toisin sanoen ei ole olemassa työtä ilman työntekijöitä; työntekijät luovat koko ajan omalla (tiedostamattomalla tai tietoisella) toiminnallaan reunaehtojaan ja ovat itse niiden osa.

Näin ollen työtä ei voi käsittää kaksijakoisesti, annettujen reunaehtojen ja muunneltavan työntekijän "yhteensovittamisena". Työ voidaan käsittää vain kehittyvänä toimintajärjestelmänä, jonka kehitykseen voidaan tietoisesti vaikuttaa, kun tunnetaan sen oma historiallinen kehityslogiikka ja sisäiset kehitysristiriidat.

Kehittävän työntutkimuksen tehtävänä on työn kehityksen dynamiikan ja uusien kehitysmahdollisuuksien paljastaminen ja realisoiminen. Kehittävä työntutkimus kehittää työntekijöiden kykyä käsittää työprosessinsa kokonaisuutena ja vaikuttaa aloitteellisesti sen muovautumiseen; se pyrkii tekemään työntekijät työnsä subjekteiksi. Tähän pyritään erittelemällä työn kehittymistä historiallisesti ja löytämällä vallitsevasta työkäytännöstä kehittyneemmän käytännön ituja. Ennen kaikkea pyritään muodostamaan uusia, tietoisesti hallittuja välineitä kehittyneemmän käytännön saavuttamiseksi. Näiden välineiden muodostamiseen tarvitaan korkealaatuisia oppimisprosesseja, jotka puolestaan edellyttävät koulutuksellista puuttumista työhön eli "'koulutusinterventioita". Voidaan sanoa, että koulutus on kehittävän työntutkimuksen tärkein tutkimusmenetelmä.

Kehittävän työntutkimuksen kaksi tärkeintä edellytystä ovat a) teoreettinen malli työtoiminnan rakenteesta ja b) malli itse tutkimusprosessin vaiheista joka samalla on malli työprosessin kehittämisen vaiheista.

\section{Työtoiminnan rakenteen yleinen malli}

Ihmisen työtoiminnan ymmärtämiseksi on jäljitettävä sen syntyä. Kuinka eläimen toimin- 
ta eroaa ihmisen toiminnasta ja mikä on siirtymä niiden välillä? Eläimen toimintaa voidaan yksinkertaistaen kuvata kolmen osatekijän vuorovaikutuksena (kaavio 1).

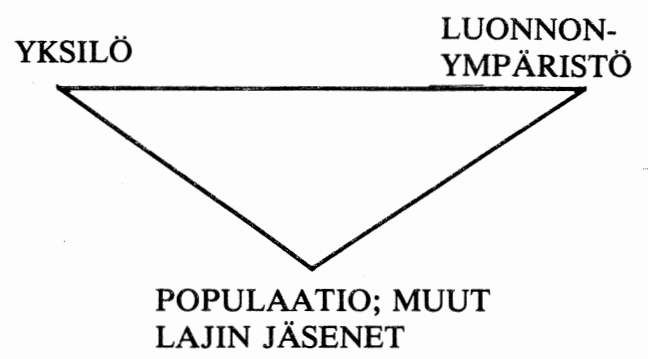

Kaavio 1. Eläinten toiminnan yleinen rakenne Eläinten toimintaa leimaa yksilön välitön ja kiinteä riippuvuus luonnonympäristöstään ja toisaalta populaatioonsa kuuluvista lajinsa muista edustajista. Yksilön mahdollisuudet itse muovata ympäristöään ja kohtaloaan kasvavat radikaalisti kehittyneillä kädellisillä, vielä suurelta osin hämärän peitossa olevassa siirtymävaiheessa kohti ihmisyyttä. Kolmion kulmien väleihin alkaa kehittyä välittäviä tekijöitä (kaavio 2).

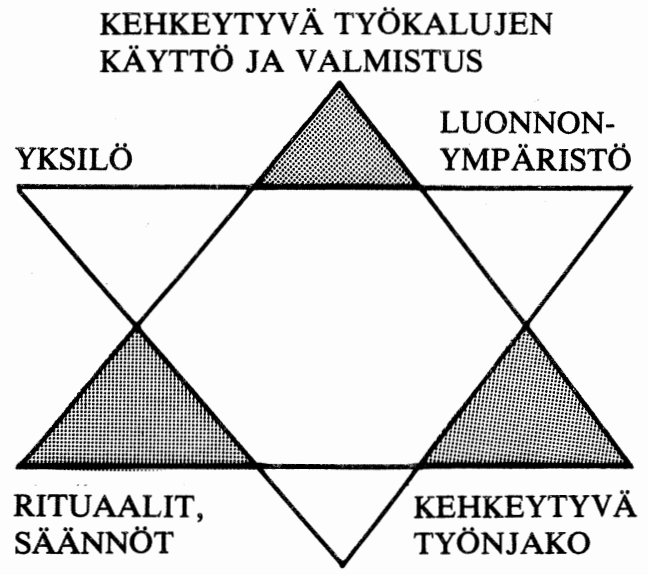

POPULAATIO

Kaavio 2. Siirtymävaihe eläimen toiminnasta ihmisen toimintaan

Systemaattisen työkalujen valmistuksen ja varastoinnin alku merkitsee läpimurtoa ihmisyyteen ja kulttuuriin: yli yksilöiden ja sukupolvien säilyviin yleisiin merkityksiin, yleistyksiin. Samalla välittävistä, tavallaan poikkeuksellisista tekijöistä - välineistä, säännöistä ja työnjaosta - tulee määrääviä. Toiminnasta tulee peruuttamattomasti yhteiskunnallista (kaavio 3).

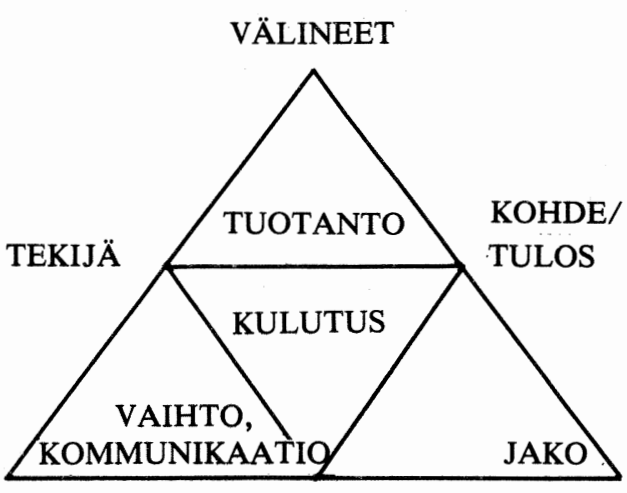

SÄÄNNÖT YHTEISÖ TYÖNJAKO

Kaavio 3. Ihmisen toiminnan yleinen rakenne

Kuten kaavio 3 osoittaa, ihmisen toiminta - jonka perusmuoto on työtoiminta - sisältää neljä osaprosessia: tuotannon, kulutuksen, jaon ja vaihdon. Vaikka joskus on tarkoituksenmukaista erottaa jokin näistä - esimerkiksi tuotanto - itsenäiseksi tarkastelun kohteeksi, tällöin on aina kyse pelkistyksestä. Todellisuudessa kaikki neljä prosessia ovat erottamattomia, ja toiminnan koko dynamiikka voidaan ymmärtää vain tarkastelemalla niiden kokonaisuutta.

Tämä ei kuitenkaan vielă riitä kuvaamaan ihmisen toiminnan rakennetta. Rakenteeseen kuuluu myös hierarkisuus. Leontjev (1977) kuvaa tätä hierarkisuutta erottamalla koko toiminnan (jota suuntaa motiivi), sitä toteuttavat teot (joita suuntaavat tavoitteet) sekä operaatiot, joiden avulla teot suoritetaan (niitä ohjaavat aineelliset suoritusehdot). Esimerkiksi tuotantolaitoksen tai viraston koko toiminta voidaan jakaa lukuisiin osatehtäviin eli tekoihin, joilla kullakin on tietoinen tavoite. Nämä teot puolestaan suoritetaan paljolti automatisoituneiden, tiedostamattomien rutiinien eli operaatioiden avulla. Ratkaisevaa toiminnan laadun kannalta on se, miten tekijät tiedostavat toiminnan kohteen, joka määrää toiminnan todellisen motiivin. Monimutkaisessa työnjaollisessa toiminnassa on tavallista, että yksittäinen työntekijä tiedostaa oikeastaan vain yksittäisten tekojensa tavoitteet, mutta ei osaa liittää niitä koko toiminnan motiiviin ja rakenteeseen, semminkin kun tuo motiivi usein on hyvin ristiriitainen. Siten yksittäisen työntekijän työmotiivi on häilyvä, epämääräinen - helpointa on kytkeä se työstä saatavaan kouriintuntuvaan kannustimeen, palkkaan.

Toiminnan kolmitasoinen rakenne voidaan nyt kuvata kaikkien kaavion 4 osatekijöiden kannalta (taulukko 1). 
Taulukossa on erityisesti kiinnitettävä huomiota sarakkeeseen "väline". Työkalu on tietoisen tekijän väline vasta silloin, kun tekijä muodostaa mallin työkalusta ja sen käyttö/ valmistustavasta. Mallien muodostamisessa yksilöä ohjaa jokin yleinen näkemys siitä, mi- ten malleja (käsitteitä, teorioita) ylipäänsä muodostetaan, millaisia niiden "tulee olla", toisin sanoen jokin enemmän tai vähemmän tiedostettu metodologia tai ideologia. Metodologiat ja ideologiat puolestaan syntyvät kollektiivisen ponnistelun tuloksina ja välineinä.

Taulukko 1. Toiminnan hierarkinen rakenne

\begin{tabular}{|c|c|c|c|c|c|c|}
\hline Yksikkö & Tekijä & Väline & Kohde & Yhteisö & Säännöt & Työnjako \\
\hline $\begin{array}{l}\text { Toiminta } \\
\text { (motiivi) }\end{array}$ & $\begin{array}{l}\text { Kollektiivi, } \\
\text { yhteisö }\end{array}$ & $\begin{array}{l}\text { Metodologia, } \\
\text { maailmankat- } \\
\text { somus }\end{array}$ & $\begin{array}{l}\text { Me maail- } \\
\text { massa }\end{array}$ & $\begin{array}{l}\text { Kulttuuri, } \\
\text { luokka, yh- } \\
\text { teiskunnal- } \\
\text { linen liike }\end{array}$ & $\begin{array}{l}\text { Yhteiskun- } \\
\text { nalliset } \\
\text { (valtio, la- } \\
\text { ki, uskon- } \\
\text { to...). }\end{array}$ & $\begin{array}{l}\text { Yhteiskun- } \\
\text { nallinen } \\
\text { (kansanta- } \\
\text { louden sek- } \\
\text { torit, luo- } \\
\text { kat...) }\end{array}$ \\
\hline $\begin{array}{l}\text { Teko } \\
\text { (tavoite) }\end{array}$ & Yksilö & Malli & Ongelma & $\begin{array}{l}\text { Kollektiivi, } \\
\text { työyhteisö }\end{array}$ & $\begin{array}{l}\text { Organisa- } \\
\text { toriset }\end{array}$ & $\begin{array}{l}\text { Organisa- } \\
\text { torinen }\end{array}$ \\
\hline $\begin{array}{l}\text { Operaatio } \\
\text { (suoritus- } \\
\text { ehdot) }\end{array}$ & Ei-tietoinen & Työkalu & Vastus & $\begin{array}{l}\text { Välitön pri- } \\
\text { maariryhmä }\end{array}$ & $\begin{array}{l}\text { Yksilöiden } \\
\text { väliset }\end{array}$ & $\begin{array}{l}\text { Yksilöiden } \\
\text { välinen }\end{array}$ \\
\hline
\end{tabular}

\section{Kehittävän työntutkimuksen vaiheet}

Kehittävän työnturkimuksen lähtökohtana on tutkittavan työn alustava rajaaminen ja siihen perehtyminen esim. asiantuntijahaastattelujen, havainnoinnin tai itse työhön osallistumisen avulla, samoin kyseistä työtä koskevaan ajankohtaiseen keskusteluun tutustumalla. Tätä vaihetta voidaan nimittää ilmiötason perehtymiseksi. Sen tuotoksena on alustava, rajattu kuvaus tutkimuskohteesta.

Toisena vaiheena on työn varsinainen analyysi, joka käsittää (a) itse työn kehityksen kohdehistoriallisen analyysin, (b) työn pohjaksi muodostuneiden teorioiden ja käsitysten teoriahistoriallisen analyysin sekä (c) työntekijöiden nykyisten työtapojen ja ajattelumallien aktuaaliempiirisen analyysin.

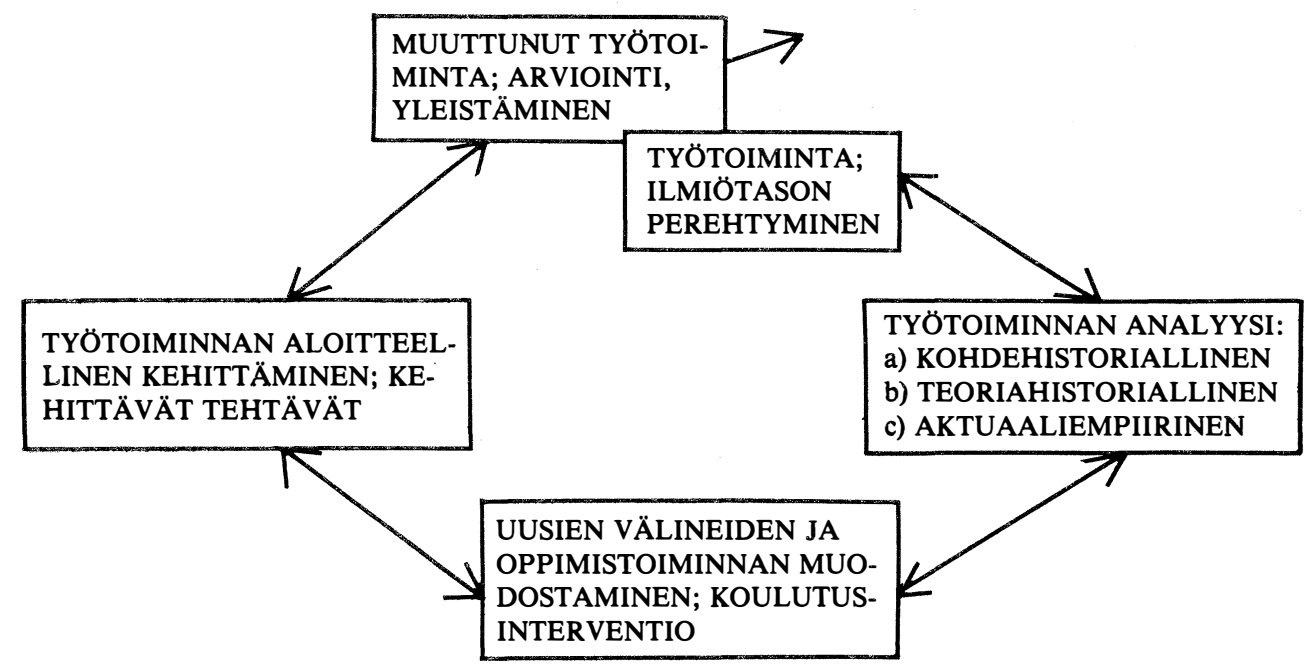

Kaavio 4. Kehittävän työntutkimuksen vaihemalli 
Näiden analyysien tuloksena määritellään työn kehitysristiriidat ja luonnostellaan työn seuraava laadullinen kehitysaskel eli lähikehityksen vyöhyke.

Kolmantena vaiheena on lähikehityksen vyöhykkeen vaatimien uusien välineiden ja mallien muodostaminen koulutusintervention ja sitä tukevien muiden mahdollisten toimenpiteiden avulla. Koulutusinterventio ei tähtää ainoastaan jonkin määrätyn uuden välineen tai mallin omaksumiseen, vaan myös työntekijöiden uudenlaisen, tutkivan ja tuottavan oppimistavan (oppimistoiminnan) kehittämiseen. Käytännössä jo työn analyysi voi tapahtua koulutusintervention muodossa, mutta intervention ydin on uusien välineiden ja uuden oppimistavan muodostaminen.

Neljäntenä vaiheena on työn aloitteellinen kehittäminen varsinaisessa arkisessa työtoiminnassa. Tämä merkitsee, että lähikehityksen vyöhykkeen saavuttamiseksi valitaan tiettyjä strategisia tehtäviä (kehittäviä tehtäviä), joissa uusia välineitä ja malleja ryhdytään viemään käytäntöön. Toisin sanoen uutta työn kehitysvaihetta ei saavuteta kertaheitolla, vaan lähikehityksen vyöhykkeellä edetään askelittain. Uusi työn kehitysvaihe "kasvatetaan" aikaisemman sisältä ja osin sen rinnalle. Tämän vaiheen tuloksena on dokumentoitua tietoa em. strategisten tehtävien toteuttamisesta ja tuloksista - ts. siitä, miten uuden työtavan toteuttaminen on onnistunut.

Viides vaihe on muuttuneen työkäytännön ja samalla koko kehittämissyklin arviointi, välitaseen teko seuraavan kehittämissyklin pohjaksi. Tämä merkitsee samalla yleistysten tekoa, kyseistä työtä ja sen kehittämistä koskevan teorian ja käsitteistön kehittelyä, viime kädessä koko kehittävän työntutkimuksen metodologian arviointia ja kehittelyä. Tämän vaiheen tuloksena on yhtä kokonaista tutkimusja kehittämissykliä koskeva raportti.

Kuten kaavion 4 kaksisuuntaiset nuolet antavat ymmärtää, kehittävän työntutkimuksen vaiheet eivät mekaanisesti seuraa toisiaan. Todellisessa tutkimusprosessissa esiintyy aina vaiheiden rinnakkaisuutta ja kaksisuuntaisia siirtymiä niiden välillä.

\section{Kohdehistoria ja teoriahistoria}

Edellä totesimme, että työtoimintaa analysoidaan kohdehistoriallisesti ja teoriahistoriallisesti. Näiden kahden analyysitavan ero käy ilmi tarkasteltaessa kaaviota 5.

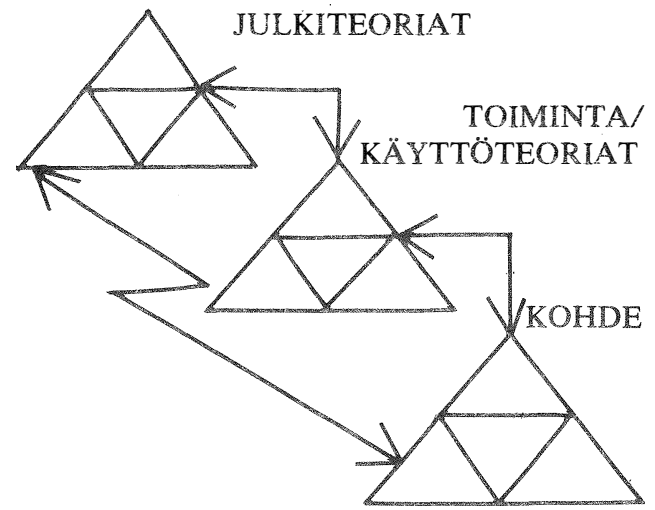

Kaavio 5. Julkiteoriat, toiminta ja kohde

Kaaviossa keskimmäinen kolmio edustaa varsinaista tutkittavaa toimintaa. Kyseisen toiminnan kohde on itsekin käsitettävä toimintana, ei kuolleena esineenä. Vastaavasti toiminnan pohjaksi ja välineiksi tuotetaan julkiteorioita aivan erityisen toiminnan, esimerkiksi tutkimuksen avulla. Julkiteoriat eivät kuitenkaan suoranaisesti ohjaa toiminnan käytäntöä. Käytäntö synnyttää omat, usein vain heikosti tiedostetut "käyttöteoriansa" toiminnan kohteesta, ja julkiteoriat voivat tehokkaasti ohjata käytäntöä vain näiden välityksellä. Julkiteoriat ovat usein etäällä toiminnan kohteesta, enemmän tai vähemmän ristiriidassa sen kanssa. Kaikkien kolmen kolmion välillä vallitsevat siis jännitteiset suhteet.

Kohdehistoriallinen analyysi edellyttää ennen kaikkea toiminnan kohteen historiallisen kehityksen erittelyä. Teoriahistoriallinen analyysi taas edellyttää toiminnan käsittämiseksi ja ohjaamiseksi tuotettujen julkiteorioiden historiallista erittelyä. Näiden kahden kautta päästään itse toiminnan, keskimmäisen kolmion, kohteeseen ja välineisiin.

Esimerkin tällaisesta ajattelusta tarjoaa tanskalaisen filosofin Uffe Juul Jensenin (1983) teos "Sairauskäsitteet käytännössä: kliinisen työn filosofia ja tieteenteoria". Kirjoittaja aloittaa teoksensa analysoimalla lääkäreiden ja muiden kliinisiin kollektiiveihin kuuluvien työn julkiteorioita eli teorioita sairauden ja taudinmäärittelyn luonteesta. Hän osoittaa näiden julkiteorioiden riittämättömyyden kliinisen työn käytännön kannalta ja ryhtyy sitten erittelemään kliinisen työn käytännön ja käyt. töteorioiden historiallista muovautumista, käytännön menettelytapoja sairauksien toteamisessa ja käsittelyssä. Hän päätyy osoittamaan, että kliinisen työn kriisin voittaminen edellyttää, että tuon työn piiriin sisällytetään työn kohteen eli sairauksien tutkiminen ihmisten koko elämäntoiminnan kannalta, siis sen 
jatkuva tutkiminen, mitä tarkoittaa "ihmisarvoinen elämä". Tämä on välttämätöntä siksikin, että kliinisten kollektiivien toiminta ja arkiteoriat käytännössä koko ajan vaikuttavat myös kohteeseen eli sairauksiin ja muokkaavat niitä: hoito ja ennaltaehkäisy muuttaa sairauksien luonnetta ja "synnyttää" uusia. Sairaus ei ole itsenäinen, muuttumaton olio, vaan ihmisten historiallisesti kehittyvän elämäntoiminnan ilmaus.

Entä miten tämä soveltuu vaikka autojen valmistustyöhön? Kohdehistoriallinen analyysi edellyttää, että tutkimme tämän työn kohteen, siis valmistettavan auton, kehitystä ihmisten toiminnan (liikkumisen, yhteydenpidon) välineenä. Teoriahistoriallinen analyysi edellyttää, että tutkimme "hyvää autoa" ja "hyvää autonvalmistusta" koskevien julkiteorioiden kehitystä suhteellisen itsenäisenä toimintana, jota voidaan nimittää autonsuunnitteluksi ja siihen liittyväksi tutkimukseksi. Näistä porteista saamme lisävaloa itse autonvalmistustoiminnan kohteiden ja välineiden kehityksen ymmärtämiseksi.

Työn historiallinen analyysi voidaan käynnistää kysymällä, millaista kyseinen työ oli ennen, siis sellaisessa aikaisemmassa vaiheessa, joka laadullisesti selvästi poikkesi nykyisestä. Seuraavaksi voidaan kysyä, millaista työ on nyt ja minkälaisten siirtymävaiheiden kautta nykytilanteeseen on tultu. Koko ajan erittelyn välineenä käytetään työtoiminnan yleisen mallin sisältämiä rakennetekijöitä (kaavio 3): kuka teki, millä välineillä, mitä teki, keiden kanssa, millä säännöillä, millä työnjaolla. Mutta tämän mallin rinnalle tarvitaan analyysin välineeksi käsitystä palkkatyön yleisistä kehitystyypeistä.

\section{Työn historialliset kehitys- tyypit ja sisäiset ristiriidat}

Oman aikakautemme vallitsevan työmuodon, palkkatyön kehityshistoria osoittaa, että mitä erilaisimmat työprosessit ja ammatit ovat käyneet läpi tiettyjä pitkälti samankaltaisia kehitysvaiheita. Näistä voidaan yleistää ja pelkistää esiin neljä työn historiallista kehitystyyppiä (vrt. Toikka 1982; Engeström \& Engeström 1984, 18-21) Näitä nimitämme (1) käsityömäiseksi työksi, (2) rationalisoiduksi työksi, (3) humanisoiduksi työksi sekä (4) teoreettisesti hallituksi työoksi. Nämä historialliset kehitystyypit ovat teoreettisia abstraktioita. Ne eivät todellisuudessa esiinny "puhtaina", vaan osin rinnakkaisina ja toisiinsa kietoutuneina.

Käsityömäisessä työssä työnjako on vähäistä, yksin työskentelevä tekijä muokkaa kohteensa pitkälti "'alusta loppuun", käsityökaluja ja kokemustietoa hyväksikäyttäen. Rationalisoidussa työssä työ on ositettu ja hierarkisoitu tehokkuuden ja suurten sarjojen saavuttamiseksi; työntekijä on anonyymi ja voimaton osanen suuressa koneistossa, jota ohjaillaan hänen päänsä yläpuolella. Humanisoidussa työssä työntekijöiden ryhmien tai solujen autonomisuutta on laajennettu antamalla niille vaikutusvaltaa oman työrytminsä ja sisäisen työnjakonsa suhteen. Vihdoin teoreettisesti hallitussa työssä työntekijöiden tietoisuus ja vaikutusvalta ulotetaan koskemaan koko toiminnan kehitystä, sen kohteita ja tuotteita, käytettävää teknologiaa ja organisaatiota; uusien mallien ja strategioiden kehittely eli tutkiva ja tuottava oppimistoiminta tulee kiinteäksi osaksi työtä.

Tämä peräkkäisten työtyyppien luonnehdinta vaikuttaa yksinkertaiselta ja mutkattomalta. Työtyyppien olemassaololle, jopa viimeksimainitun teoreettisesti hallitun työn orastamiselle, löytyy runsaasti todistusaineistoa. Työtyypit ovat tehokas heuristinen väline kohdeja teoriahistoriallisessa analyysissa - kunhan muistetaan, että mitään työtä ei voi mekaanisesti, ulkokohtaisesti puristaa valmiiden työtyyppien muotteihin, vaan joka kerran on kysymys aidosta työn "sisältä käsin" lähtevästä historiallisesta erittelystä, joka voi myös muovata edelleen käsitystämme työtyypeistä.

Mutta tästä vasta ongelma alkaa. Mikä saa aikaan siirtymät työtyypistä toiseen? Miten on ymmärrettävissä työn kehittyminen?

Työn kehitys on työn yhteiskunnallistumista, joka ilmenee tuotteiden yhteiskunnallisten vaikutusten laajenemisena, työorganisaatioiden monimutkaistumisena ja työn teoreettisen välineistön kasvuna. Palkkatyön historialliset kehitystyypit ovat samalla työn yhteiskunnallistumisen askelmia. Työn "'kehitysmekanismi" on työn sisäisten ristiriitojen kypsyminen pisteeseen, joka vaatii laadullista muutosta työtoiminnan kaikissa osatekijöissä ja niiden suhteissa. Näitä sisäisiä ristiriitoja voidaan eritellä kolmella tasolla:

1) Yleisimmällä tasolla työn sisäinen ristiriitaisuus ilmenee palkkatyön kaksinaisluontees$s a$ : työllä pyritään ylhäältä hyödyllisten, konkreettisten ja toimivien käyttöarvojen valmistukseen (käyttöarvonäkökulma), toisaalta liiketaloudelliseen voittoon, kannattavuuteen tai "taloudellisuuteen", joka abstrahoituu tuot- 
teiden sisällöstä ja laadusta, tekee siitä tavallaan yhdentekevän (vaihtoarvonäkökulma). Tästä seuraa, että kaikkiin toiminnan ongelmiin on rinnakkain (usein saman henkilön päässäkin) kaksi kilpailevaa näkökulmaa, ratkaisu- ja arviointiperustetta. Esim. uuden teknologian käyttöönotossa on usein ensimmäisenä perusteena saavutettava työvoimakustannusten säästö, mikä merkitsee samalla välinpitämättömyyttä työn sisällön muutosta ja siitä seuraavia ammattitaito- ja koulutustarpeita kohtaan. Mutta tuotteiden laadussa ja tuotannon kulussa ilmenevät häiriöt ja konfliktit pakottavat suuntaamaan huomion sisältöihin. Seuraa enemmän tai vähemmän hallittu työn laadullisen uudelleenjärjestelyn vaihe.

2) Toiseksi työn sisäiset ristiriidat ilmenevät työtoiminnan rakennetekijöiden (ks. kaavion 3 kolmiomalli ja taulukon 1 hierarkia) välisinä kehitysjännitteinä. Esimerkiksi edellä luonnehdittua uuden teknologian käyttöönottoa luonnehtii usein voimakas jännite uusien välineiden ja työn tekijöiden välillä: tekijät kokevat välineet vaikeiksi hallita. Vastaavasti jännite voi ilmetä muuttuneen kohteen ja entisellään säilyneiden välineiden välillä: esim. kliinisen kollektiivin pitäisi käsitellä oireita, joihin ei ole olemassa valmiita menettelytapoja.

3) Kolmanneksi työn sisäiset ristiriidat esiintyvät työntekijöiden ajattelussa ja toiminnassa, tiedollis-taidollisina, motivationaalisina ja yhteistoiminnallis-sosiaalisina jännitteinä. Näiden jännitteiden hallitsemiseksi työntekijät myös kehittävät, usein tiedostamattaan, uusia ja omaperäisiä, työn tulevaa kehitystä enteileviä menettelytapoja ja välineitä.

Tämä ristiriitojen kolmas taso johtaa meidät työorientaatioiden tarkasteluun.

\section{Työorientaatiot ja mallit}

Kohdehistoriallisen ja teoriahistoriallisen analyysin lisäksi työtä on eriteltävä aktuaaliempiirisesti. Tämä merkitsee, että tutkitaan, miten työtä tehdään ja miten se käsitetään nyt, käytännössä. Aktuaaliempiirinen analyysi on usein kehittävän työntutkimuksen suuritöisin vaihe. Kyse ei ole ainoastaan työn ulkoisen kulun havainnoimisesta ja kuvaamisesta (vrt. toimenkuvaukset, työnkulkukuvaukset, tietovirtojen kuvaukset), vaan työntekijöiden työn hallinnan erittelystä työorientaation käsitteestä lähtien.

Työnorientaatiolla tarkoitetaan kollektiivisia ja yksilöllisiä ajattelu- ja toimintamalleja, joilla työtä ohjataan ja säännellään. Edellä erotimme julkiteoriat ja käyttöteoriat -- tämä on yksi tapa jaotella työorientaatioita. Vähintään yhtä tärkeää on erottaa toisistaan (a) koko työtoiminnan tason mallit (esim. käsitykset työn kokonaiskohteesta ja -tuloksesta, työn. tulevasta kehityksestä jne.), (b) yksittäisiä työsuorituksia eli tekoja koskevat mallit ja (c) rutiinimaisia operaatioita koskevat mallit. Näiden kolmen tason mallien välillä esiintyy usein työn hallinnan kannalta tärkeitä ristiriitoja ja jännitteitä: esim. työntekijällä on erittäin kehittynyt kuva jostakin työsuorituksesta, mutta heikko käsitys työprosessin kokonaisuudesta.

Työorientaatiot on kaikilla kolmella tasollaan käsitettävä ajattelutavan ja tekemistavan yhdistelminä. Esim. haastattelussa julkilausuttu ajattelutapa antaa vasta puolinaisen kuvan työorientaatiosta - toinen puoli on työntekijän (tai ryhmän) toimintatapa käytännön tehtävissä. Myös näiden kahden puolen, sanojen ja tekojen, väliset ristiriidat ovat tärkeitä työn hallinnon ymmärtämiseksi.

Työorientaatioiden erittelyssä on hedelmälliseksi osoittautunut niiden luokittelu viiteen erilaista logiikkaa edustavaan tyyppiin (ks. Engeström 1984):

1) Historiallisesti primitiivisintä orientaatiotyyppiä edustavat spontaanit mallit; ne esiintyvät elämyksellis-kuvallisina "prototyyppeinä', jotakin ilmiöluokkaa edustavina esimerkkitapauksina, joita subjektin on usein vaikea tietoisesti eritellä.

2) Ennakkojäsentäjät ovat malleja, joissa jokin kohde tai ilmiö on jaoteltu osasiinsa, luokiteltu, luetteloitu tai hierarkisoitu joidenkin yhteisten ja erottavien tuntomerkkien perusteella. Näiden mallien rajoituksena on niiden staattisuus - ne eivät kuvaa prosesseja.

3) Algoritmit eli vaiheistetut prosessikuvaukset tai suoritusohjeet kuvaavat taphtumista, liikettä, mutta tiukan deterministisesti jaettuna alkupisteestä loppupisteeseen eteneviin vaiheisiinsa. Tällaiset mallit eivät pysty kuvaamaan vuorovaikutuksia.

4) Systeemikuvaukset ovat malleja, joilla pyritään vuorovaikutusten, palautekytkentöjen, samanaikaisten prosessien ja kokonaisuuksissa tapahtuvien muutosten kuvaamiseen käyttäen apuna todennäköisyyksiä eikä ehdotonta ennaltamäärättyä peräkkäisyyttä. Tällaiset mallit muodostuvat helposti monimutkaisiksi tasapainokuvauksiksi; järjestelmien sisäiset ristiriidat, niiden geneettinen alkuperä ja historiallinen kehitys eivät näin hahmotu.

5) "Alkusolumallit" pyrkivät kuvaamaan järjestelmien alkuperäisiä, yksinkertaisia sisäisiä suhteita ristiriitaisina ja siksi historiallista kehitystä (järjestelmän kokonaislaadun muut- 
tumista) aiheuttavina.

Kehittynyt työn hallinta edellyttää näiden kaikkien viiden tyypin hyödyntämistä, kykyä siirtyä mallityypistä toiseen ja johtaa esim. spesifimpejä malleja yleispätevämmistä. Ennakkojäsentäjät vastaavat kysymyksiin "'mitä?" ja "minkälaista?', algoritmit kysymykseen "miten?", systeemimallit kysymykseen "missä kokonaisuudessa?"' ja alkusolumallit kysymykseen "miksi?". Oleellista on mallien tuottaminen ja soveltaminen käytäntöön. Eri tyyppisillä malleilla on omat tyypilliset tuottamis- ja soveltamistapansa.

Mallit voidaan myös ilmaista ja hallita erilaisilla "kielillä" - fyysisten eleiden ja liikkeiden, esineiden, kuvien ja kaavioiden, sanojen tai matemaattisten symbolien avulla. Jonkintyyppisen mallin esiintyminen tai puuttuminen saattaa tutkimustuloksena olla sidoksissa tutkimustilanteessa tai kokeessa käytettyyn "'kieleen" - toista "'kieltä" käytettäessä tulos voisi olla toisenlainen.

\section{Lähikehityksen vyöhyke}

Kohdehistoriallinen, teoriahistoriallinen ja aktuaaliempiirinen analyysi tähtäävät kaikki yhteiseen päämäärään: työtoiminnan kehitysristiriitojen tunnistamiseen ja lähikehityksen vyöhykkeen johtamisen niiden pohjalta. Lähikehityksen vyöhykkeen johtaminen eroaa siis esim. futurologisista ennusteista. Kysymys on tutkittavan työn historiallisen kehityslogiikan löytämisestä ja sen pohjalta seuraavaa laadullista kehitysvaihetta koskevan hypoteesin luonnostelusta.

Lähikehityksen vyöhyke voidaan määritellä seuraavasti:

Lähikehityksen vyöhyke on nykyisessä työtoiminnassa esiintyvien yksilöllisten tekojen ja pitemmälle yhteiskunnallistuneen, laadullisest $i$ uuden yhteisen työtoiminnan välinen intensiivisen muutoksen alue, joka voidaan kollektiivisesti tuottaa ratkaisuna nykyisessä toiminnassa esiintyviin ristiriitoihin.

Määritelmä on näin kiteytettynä hankala ymmärtää. Kyse on yksinkertaisesti siitä, että hahmotellaan kyseisen työn nykyisten ristiriitojen ratkaisuksi uusi, kehittyneempi työtoiminnan vaihe (jälleen käyttăen välineenä kaavion 3 mallia työtoiminnan rakennetekijöistä). Näin hahmoteltu "ihannemalli" on todellakin vasta alustava hypoteesi. Sen konkretisoinnissa on kaksi ratkaisevaa edellytystä. Ensinnäkin on tarkoin eriteltävä, mikä ovat kehitysvaiheen edellyttämät uudet välineet, sekä aineelliset työkalut että ajattelumallit. Toiseksi on määriteltävä uuden kehitysvaiheen saavuttamisen kannalta strategiset kehittävät tehtävät, joissa ryhdytään käyttämään uusia välineitä uudenlaisten tulosten tuottamiseksi.

Esimerkiksi Robert Arnkilin (1985) tutkimuksessa ammatinvalinnanohjaajien työn kehittämisestä käytettiin kahta kehittävää tehtävää. Ohjaajien tuli ensinnäkin vajaan vuoden ajan laatia kirjallinen asiakasmuistio jokaisesta kohtaamastaan asiakkaasta. Toiseksi ohjaajat suunnittelivat ja toteuttivat yhteistyössä opinto-ohjaajien kanssa pienimuotoisen työkasvatusprojektin toimialueensa peruskoulun yhdeksäsluokkalaisille.

Lähikehityksen vyöhykkeen hahmottelu ja ennen kaikkea sen konkretisointi välineiksi ja kehittäviksi tehtäviksi edellyttää koulutusinterventioita, joissa työntekijät itse ryhtyvät erittelemään työtään ja muovaamaan uusia malleja.

Samalla koulutusinterventiot tähtäävät työntekijöiden oppimistoiminnan muodostamiseen.

\section{Oppimistoiminta}

Tutkiva ja tuottava oppimistoiminta on pitemmällä tähtäyksellä välttämätön edellytys sille, että työntekijöistä ei tule ainoastaan uusien välineiden käyttäjiä, vaan myös niiden kehittäjiä - ei ainoastaan lähikehityksen vyöhykkeelle etenijöitä, vaan myös seuraavien vyöhykkeiden hahmottelijoita.

Oppimistoiminta eroaa sekä perinteisestä "työssä oppimisesta" että tavanomaisesta kouluoppimisesta. Perinteisen "työssä oppimisen" rajoitus on vahvojen käsitteellisten välineiden ja mallien puuttuminen, kun oppiminen alistetaan arkityön logiikalle. Kouluoppimisen rajoitus on käsitteiden ja mallien saaminen valmiina, kuolleena tietona, johtamatta niitä käytännöstä ja soveltamatta niitä käytäntöön. Kummallakaan tavalla ei synny objektiivisesti uutta tietoa, uusia välineitä ja malleja, muutoin kuin poikkeustapauksissa. Oppimistoiminnassa on kysymys objektiivisesti uusien todellisuutta kuvaavien mallien tuottamisesta.

Tällaisella oppimistoiminnalla on tietty psykologinen rakenne; se koostuu määrätyistä oppimisteoista, jotka on tietoisesti hallittava (Dawydow, Lompscher \& Markowa 1982; Engeström 1983). Oppimistoiminta tähtäă teoreettisen ajattelun muodostamiseen. Teoreettinen ajattelu tai teoreettinen suhde todellisuuteen merkitsee, että työntekijä käsittäă työnsä ja sen kohteen systeemisenä ja sisäisten ristiriitojensa kautta historiallisesti kehittyvänă. On- 
gelmatilanteessa hän kykenee ottamaan etäisyyttä ongelmasta, tarkastelemaan sitä laajemmassa kokonaisyhteydessään, jäljittämään ongelman synnyn, tekemään ajatuskokeita ja muodostamaan mallin ongelman ratkaisun yleisestä periaatteesta (ks. tarkemmin Engeström \& Toikka 1985).

Kaaviossa 5 esitetään yhteen kytkettynä kolme toimintaa: varsinainen tutkittava työtoiminta, sen julkiteorioiden tuottamistoiminta sekä työtoiminnan kohteena oleva toiminta. Esimerkiksi: kliinisen kollektiivin työtoiminta terveyskeskuksessa, sairausteorioita tuottava tutkimustoiminta - ja terveyskeskuksen sairaiden asiakkaiden elämäntoiminta. Oppimistoiminta on neljäs toiminta, joka tulee kytkeä suoraan mainittuihin kolmeen. Se on itse asiassa edellytys sille, että työntekijät voivat tietoisesti kytkeä muut kolme toimintaa yhteen.

\section{Kehittävän työntutkimuksen käytäntö}

Kehittävän työntutkimuksen luonteenomainen piirre on tietynlainen "epäakateemisuus". Tutkimus kytkeytyy yleensä kiinteästi käytännölliseen muutos- tai kehittämishankkeeseen työssä ja organisaatiossa. Se mikä tutkijalle on kehittävää työntutkimusta, on esimiehelle, kouluttajalle tai työntekijälle tutkivaa työn kehittämistä. Ero on liukuva.

Epäakateemisuus ei merkitse epäteoreettisuutta. Kehittävä työntutkimus on teoreettisempaa ja käytännöllisempää kuin tavanomainen toteava, korjaava tai pyhittävä tutkimus.

Kehittävän työntutkimuksen hankkeet ovat tyypillisesti kollektiivisia ja usein monitieteisiä. Esimerkiksi Valtion teknillisessä tutkimuskeskuksessa tietokoneohjattua FMS-tuotantoa tutkivassa ryhmässä insinööri, sosiologi ja psykologi työskentelevät kiinteässä vuorovaikutuksessa tutkittavan tuotantolaitoksen insinöörien ja ammattityöntekijöiden kanssa. Pedagogia, koulutuksen ja oppimisen tuntijaa, tarvittaisiin jokaisessa kehittävän työntutkimuksen hankkeessa.

Teoreettista ja metodologista perustaa kehittävälle työntutkimukselle on muovattu mm. Kari Toikan (1984) kirjassa 'Kehittävä kvalifikaatiotutkimus" sekä Toikan, Engeströmin ja Norroksen (1985) laajassa artikkelissa "'Entwickelnde Arbeitsforschung". Orientaatioiden ja mallien teoriaa on kehitelty tutkimuksessa "Orientointi opetuksessa" (Enge- ström 1984) ja oppimistoiminnan teoriaa teoksessa "Oppimistoiminta ja opetustyö" (Engeström 1983). Eri tutkimushankkeista on julkaistu joukko esi- ja osaraportteja sekä artikkeleita. Toistaiseksi pisimmälle raportoitu empiirinen hanke on siivoustyötä koskeva tutkimus, josta on julkaistu kirja "Siivoustyön hallinta ja siivoojien laadullinen koulutustarve"" (Engeström \& Engeström 1984). Nordisk Pedagogik -lehden numero $1 / 1986$ on omistettu kehitettävälle työntutkimukselle ja toiminnan teorialle.

\section{Lähteet}

Arnkil, R. 1985. Kehittävăt sisällolliset tehtävăt koulutus- ja tutkimusmenetelmänä ammatinvalinnanohjaustyössä. Julkaisussa L. Lestinen (toim.) Tieteellisen koulutuksen nykykohtia. Kasvatustieteiden tutkimuslaitos. Selosteita ja tiedotteita 260.

Dawydow, W.W., Lompscher, J. \& Markowa, A. (Hrsg.) 1982. Ausbildung der Lerntätigkeit bei Schülern. Berlin: Volk und Wissen.

Engeström, Y. 1983. Oppimistoiminta ja opetustyŏ. Helsinki: Tutkijaliitto.

Engeström, Y. 1984. Orientointi opetuksessa. Valtion koulutuskeskus. Julkaisusarja B n:o 29.

Engeström, Y. \& Engeström, R. 1984. Siivoustyön hallinta ja siivoojien laadullinen koulutustarve. Helsinki: Servi Systems Oy.

Engeström, Y. \& Toikka, K. 1985. Teoreettisen ajattelun käytännöllinen perusta. Julkaisussa L. Lestinen (toim.) Tieteellisen koulutuksen nykykohtia. Kasvatustieteiden tutkimuslaitos. Selosteita ja tiedotteita 260.

Fricke, E. \& al. 1981. Qualifikation und Beteiligung. Frankfur am Main: Campus.

Jensen, U. J. 1983. Sygdomsbegreber i praksis. Det kliniske arbejdes filosofi og videnskabsteori. Köbenhavn: Munksgaard.

Kern, H. \& Schumann, M. 1984. Das Ende der Arbeitsteilung? München: Beck.

Leontjev, A. N. 1977. Toiminta, tietoisuus, persoonallisuus. Helsinki: Kansankulttuuri.

Toikka, K. 1982. Kvalifikaation kăsitteestă ja kehitysvaihtoehdoista. Julkaisussa Kvalifikaatio ja työn vaatimukset koulutuksen suunnittelun lăhtökohtana. Valtion koulutuskeskus. Julkaisusarja B n:o 18.

Toikka, K. 1983. Arvio kirjasta Fricke, E. \& al. Aikuiskasvatus 3:3.

Toikka, K. 1984. Kehittävä kvalifikaatiotutkimus. Valtion koulutuskeskus. Julkaisusarja B n:o 25.

Toikka, K., Engeström, Y. \& Norros, L. 1985. Entwickelnde Arbeitsforschung. Theoretische und methodologische Elemente. Forum Kritische Psychologie 15.

Uspenski, E. 1981. Krokotiili Gena ja hănen ystävănsä. Helsinki: Otava. 